J. Perinat. Med. 15 (1987) 221

\section{Effects of betamethasone on maternal plasma cortiocotropin releasing factor, ACTH and cortisol during pregnancy*}

\author{
Pamela J. Tropper, Robin S. Goland, Sharon L. Wardlaw, Harold E. Fox, and \\ Andrew G. Frantz
}

Departments of Obstetrics and Gynecology and Medicine, Columbia University College of Physicians and Surgeons, New York, U.S.A.

\section{Introduction}

High levels of corticotropin releasing factor immunoactivity (CRFi), a hypothalamic releasing hormone which stimulates pituitary $\beta$-endorphin ( $\beta$-EP) and ACTH secretion, are present in the plasma of women during the second half of pregnancy $[2,7]$. This is in distinction to the undetectable or extremely small amounts of the hypothalamic releasing factor which have been reported in the peripheral plasma of healthy non-pregnant adults [9]. The CRFi measurable in the plasma of non-pregnant adults appears to be of hypothalamic origin [9] while there are several lines of evidence to support a placental source for the CRFi measured in the plasma during pregnancy.

A substance similar in molecular weight to CRF has been extracted from term human placentas which causes the release of ACTH and $\beta$-EP from rat anterior pituitary cells in culture [8]. In addition, we have found a highly significant correlation between simultaneously obtained maternal and fetal CRFi levels at delivery as well as a higher CRFi concentration in the umbilical vein compared to the umbilical artery, again suggesting a placental source for both maternal and fetal CRFi [2]. These results,

\footnotetext{
* This work was presented in part at the 1986 Annual Meeting of the American Federation for Clinical Research, Washington, D.C.
}

\section{Curriculum vitae}

Pamela J. Tropper, M.D., completed her training in Obstetrics and Gynecology and Maternal-Fetal Medicine at the Columbia-Presbyterian Medical Center, New York, $N$. Y. and currently serves on the faculty of the College of Physicians and Surgeons of Columbia University. Her areas of interest include placental production of corticotropin releasing factor and fetal electroencephalography.

together with the disappearance of CRFi from maternal plasma within 24 hours after delivery $[2,7]$, provide strong evidence that the placenta secretes CRFi into the maternal and fetal circulations during gestation.

Little is known about the regulation of this placental CRFi during pregnancy. We have previously reported that umbilical cord plasma $\mathrm{ACTH}$ and $\beta$-EP are inversely correlated with $\mathrm{pO}_{2}$ and $\mathrm{pH}$ [11] while no significant relationship was observed between fetal plasma CRFi and $\mathrm{pH}$ [2] suggesting that in the fetus, hypoxia and acidosis are not stimuli for increased CRFi release by the placenta. In the present study, we have examined the effects of an acute dose of betamethasone, a long-acting corticosteroid, on maternal plasma CRFi as well as ACTH and cortisol levels. Several studies have supported the concept that glucocorticoids exert their negative feedback effect at both a pituitary and a hypothalamic level $[4,6,10]$. We have 
undertaken the present study to investigate whether glucocorticoids similarly suppress the release of $\mathrm{CRFi}$ by the placenta during pregnancy.

\section{Methods}

Eleven pregnant women at $28-32$ weeks gestation were hospitalized for premature labor and treated with betamethasone to induce fetal lung maturation. Five of the 11 patients received tocolytic agents as well. Baseline $8 \mathrm{~A} . \mathrm{M}$. plasma samples were drawn for $\mathrm{CRFi}, \mathrm{ACTH}$ and cortisol measurements. Betamethasone 12 mgs was given intramuscularly to these patients at 11 P. M. and CRFi, ACTH and cortisol were again measured at $8 \mathrm{~A}$. M. the following morning.

CRFi was extracted from $1 \mathrm{ml}$ plasma with Sep-pak C-18 cartridges (Waters Associates, Milford, MA) and measured by RIA using antiserum to human CRF raised in this laboratory. Assay sensitivity was $10 \mathrm{pg} /$ tube and $44 \mathrm{pg} / \mathrm{ml}$ when $1 \mathrm{ml}$ of plasma was extracted. ACTH was extracted from $2 \mathrm{ml}$ plasma with talc tablets as described previously [3] and measured by RIA using synthetic human ACTH and the West antiserum supplied by the National Pituitary Agency. Cortisol was measured by competitive protein binding.

Samples were collected in ice-chilled glass tubes containing EDTA (for CRF determinations) or heparin (for ACTH and cortisol measurements) and were immediately centrifuged at $4{ }^{\circ} \mathrm{C}$. Plasma was either extracted for assay immediately or frozen at $-20^{\circ} \mathrm{C}$ and thawed once for assay within 2 weeks.

\section{Results}

Before the administration of betamethasone, the mean $( \pm$ SEM) plasma cortisol concentration was $21.9 \pm 3 \mathrm{ug} / \mathrm{dl}$, mean plasma $\mathrm{ACTH}$ concentration was $45.4 \pm 6.4 \mathrm{pg} / \mathrm{ml}$ and mean plasma CRFi was $180 \pm 65 \mathrm{pg} / \mathrm{ml}$ (figure 1).

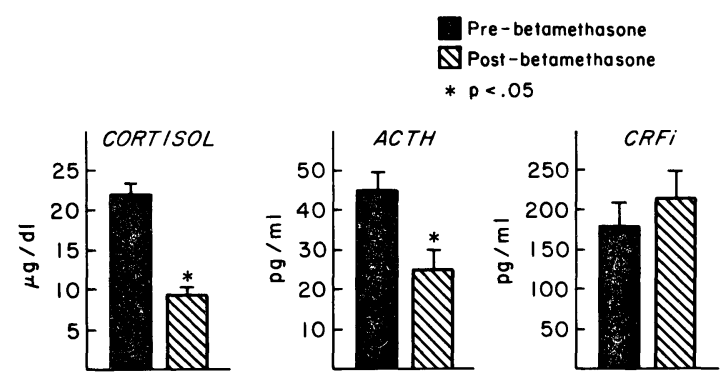

Figure 1. Effect of betamethasone on cortisol, ACTH, and CRFi concentrations in maternal plasma.

Mean maternal plasma ACTH and cortisol levels were significantly depressed after betamethasone administration while plasma CRFi remained unchanged. The mean maternal postbetamethasone ACTH concentration fell to $25.4 \pm 5.2 \mathrm{pg} / \mathrm{ml}(\mathrm{p}<0.05)$ and the mean cortisol level fell to $9.5 \pm 1.2 \mathrm{ug} / \mathrm{dl}(\mathrm{p}<0.01)$. Mean maternal plasma CRFi concentration after betamethasone was $214 \pm 69 \mathrm{pg} / \mathrm{ml}$ with a range of $48-835 \mathrm{pg} / \mathrm{ml}$.

There was no significant correlation between maternal plasma CRFi and ACTH or cortisol concentrations. As expected there was a highly significant correlation between maternal plasma ACTH and cortisol levels (figure 2).

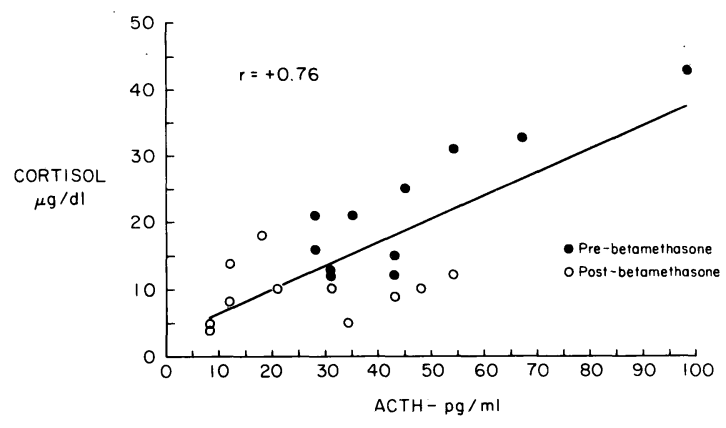

Figure 2. Correlation of ACTH and cortisol levels in maternal plasma. 


\section{Discussion}

In this study we report that the administration of betamethasone to pregnant women does not inhibit the placental secretion of CRFi into maternal plasma. Thus, the acute regulation of placental CRFi appears to be distinct from that of hypothalamic CRF. Several investigators have shown that glucocorticoids have inhibitory effects on both pituitary ACTH and hypothalamic CRF accounting for the suppression of cortisol secretion. RoBerTs et al. [6] have shown that the production of the proopiomelanocortin derived peptides, such as ACTH, is under direct negative control by glucocorticoids. An effect of glucocorticoids on CRF was demonstrated by SUDA et al. who reported that the acute administration of dexamethasone to rats caused a significant decrease in the hypothalamic CRF content [10] while in a more recent study, JingAMI et al. reported that dexamethasone administered to adrenalectomized rats lowered the messenger RNA for the CRF precursor in the hypothalamus [4]. Our finding that glucocorticoids to not inhibit placental CRF release only reflects the effects of a single dose of betamethasone. The effect of chronic treatment with glucocorticoids remains unknown.

\section{Summary}

Corticotropin releasing factor immunoactivity (CRFi) has been identified in the plasma of women in the second half of gestation. There are several lines of evidence supporting a placental source for this hormone. Regulation of placental CRFi is poorly understood. In this study, the effect of a long-acting glucorticoid on the release of placental CRFi was investigated.

Eleven women in the third trimester of pregnancy had plasma samples measured for CRFi, ACTH and cortisol
We also report a lack of correlation between CRFi and either ACTH or cortisol in maternal plasma during pregnancy. However, although the biological activity and physiologic significance of this CRFi is unknown, this lack of correlation does not exclude the possibility that placental CRFi influences ACTH and cortisol secretion during pregnancy. It is possible that placental CRFi is playing a permissive role in causing ACTH release in response to hypothalamic CRF.

The highly significant correlation between maternal ACTH and cortisol levels, with slightly elevated cortisol levels, is in agreement with the results of previous reports $[1,5]$.

In summary, we report that high levels of CRFi are present in maternal plasma in the final weeks of gestation and have previously shown that CRFi becomes detectable at 18 weeks of gestation, increases progressively with advancing gestational age, and disappears from maternal plasma within 24 hours after delivery [2]. This placental CRFi is not suppressed by betamethasone, while maternal plasma ACTH and cortisol levels are lowered by the administration of this long-acting glucocorticoid. These results suggest that the acute regulation of placental CRFi is distinct from the regulation of hypothalamic CRF.

before and after receiving $12 \mathrm{mg}$ betamethasone. There was a significant decrease in ACTH $(p<0.05)$ and cortisol levels $(p<0.01)$ but no change in CRFi. It is concluded that the secretion of CRFi by the placenta is not inhibited by the administration of betamethasone while maternal levels of cortisol and ACTH are lowered. These results suggest that the acute regulation of placental CRFi is distinct from the regulation of hypothalamic CRF.

Keywords: ACTH, betamethasone, corticotropin releasing factor, cortisol, CRF, glucocorticoids, placenta, pregnancy.

\section{Zusammenfassung}

Einfluß von Betamethason auf die maternalen Plasmaspiegel von Kortikotropin-Releasing-Faktor, ACTH und Kortisol während der Schwangerschaft

In der zweiten Schwangerschaftshälfte konnte im Plasma schwangerer Frauen ein Kortikotropin-Releasing-Faktor mit Immunaktivität (CRFi) nachgewiesen werden.
Es gibt mehrere Hinweise auf die Plazenta als Syntheseort. Über welche Regulationsmechanismen dieses Hormon gebildet wird, ist nicht bekannt. In der vorliegenden Studie wurde der Einfluß eines langwirkenden Glukokortikoids auf die Freisetzung von plazentarem CRFi untersucht. 
Bei 11 Frauen im letzten Schwangerschaftstrimenon wurden die Plasmaspiegel von CRFi, ACTH und Kortisol vor und nach Gabe von $12 \mathrm{mg}$ Betamethason bestimmt. Beim ACTH- und Kortisolspiegel kam es zu einem signifikanten Abfall ( $p<0.05$ bzw. $p<0.01$ ), der CRFi-Spiegel blieb unverändert. Wir schließen dar- aus, daß die Bildung von CRFi in der Plazenta nach Gabe von Betamethason nicht inhibiert wird, während die maternalen Plasmaspiegel von Cortisol und ACTH gesenkt werden. Die Ergebnisse zeigen, daß die Regulation des plazentaren CRFi unabhängig von der Regulation des hypothalamischen CRF erfolgt.

Schlüsselwörter: ACTH, Betamethason, CRF, Kortikotropin-Releasing-Faktor, Kortisol, Glukokortikoide, Plazenta, Schwangerschaft.

\section{Résumé}

Effets de la bétamethasone sur le corticotropin releasing factor, l'A.C.T.H. et le cortisol maternels plasmatiques pendant la grossesse

On a identifié l'activité immunologique du corticotropin releasing factor (C.R.F.i.) dans le plasma de femmes dans la seconde moitié de la grossesse. Il existe plusieurs types de preuves montrant qu'il existe une origine placentaire de cette hormone. On comprend mal la régulation du C.R.F.i placentaire. Dans cette étude, on a exploré l'effet d'un glucocorticoïde à action prolongée sur la libération du C.R.F.i placentaire.
On a mesuré au cours du troisième trimestre de la grossesse de 11 femmes les taux plasmatiques de C.R.F.i., d'A.C.T.H. et de cortisol avant et après 12 $\mathrm{mg}$ de bétamethasone. Il y a une diminution significative des taux d'A. C. T. H. $(p<0,05)$ et de cortisol $(p<0,01)$ mais pas de modification du C.R.F.i. On en conclut que le C.R.F.i d'origine placentaire n'est pas inhibé par l'administration de bétamethasone alors que les taux maternels et d'A. T.C. H. sont abaissés.

Ces résultats suggèrent que la régulation fine $d u$ C.R.F.i. placentaire est distincte de la régulation $d u$ C. R.F. hypothalamique.

Mots-clés: A. C. T. H., bétamethasone, Corticotropin releasing factor, cortisol, C. R.F, glucocorticoïdes, grossesse, placenta.

Acknowledgements: This work was supported by USP Health Service Grant HD06585 and 2 P50 HD13063. The authors would like to thank Drs. INGe DYRENFURTH and WYLIE HeMBreE for performing the cortisol determinations.

\section{References}

[1] Abou-Samra AB, M Pugeat, h Dechaud, L NaCHURY, B Bouchareb, M FeVRe-Montange, J TOURNIAIRE: Increased plasma concentration of $\mathrm{N}$ terminal $\beta$-lipotrophin and unbound cortisol during pregnancy. Clin Endocrinol 20 (1984) 221

[2] Goland RS, SL WardLaW, RI Stark, LS Brown, AG FRANTZ: High levels of corticotropin releasing factor immunoactivity in maternal and fetal plasma during pregnancy. J Clin Endocrinol Metab (in press)

[3] Goland RS, SL Wardlaw, RI Stark, AG FRANTZ: Human plasma $\beta$-endorphin during pregnancy, labor and delivery. J Clin Endocrinol Metab 52 (1981) 74

[4] Jingami H, S Matsukura, S Numa, H Imura: Effects of adrenalectomy and dexamethasone administration on the levels of prepro-corticotropin releasing factor messenger ribonucleic acid (mRNA) in the hypothalamus and adrenocorticotropin/ $\beta$-lipotropin precursor mRNA in the pituitary of rats. Endocrinology 117 (1985) 1314
[5] Rees LH, CW Burke, T Chard, SW Evans, L LETCHWORTH: Possible placental origin of ACTH in normal pregnancy. Nature 254 (1975) 620

[6] Roberts JL, CLC Chen, JH Eberwine, MJQ EvINGER, E HERBERT, BS SCHACHTER: Glucocorticoid regulation of proopiomelanocortin gene expression in rodent pituitary. Recent Prog Horm Res 38 (1982) 227

[7] Sasaki A, AS LiotTa, MM Luckey, AN MarGIORIS, T SUDA, DT KRIEGER: Immunoreactive corticotropin-releasing factor is present in human maternal plasma during the third trimester of pregnancy. J Clin Endocrinol Metab 59 (1984) 812

[8] Shibasaki T, E Odagiri, K Shizume, N Ling: Corticotropin-releasing factor-like activity in human placental extracts. J Clin Endocrinol Metab 55 (1982) 384

[9] Suda T, NI TOMORI, F YaJima, T Sumitomo, Y NAKAGAMI, T USHIYAMA, H DEMURA: Immunoreactive corticotropin releasing factor in human plasma. 
The program of the sixty-seventh meeting of the Endocrine Society, Baltimore, MD, June 19-22, 1985, Abstract 991

[10] Suda T, N Tomori, F Tozawa, T Mouri, H DeMURA, K SHIZUME: Effect of dexamethasone on immunoreactive corticotropin-releasing factor in the rat median eminence and intermediate-posterior pituitary. Endocrinology 114 (1984) 851
[11] Wardlaw SL, RI Stark, L Baxi, AG Frantz: Plasma B-endorphin and B-lipotropin in the human fetus at delivery: correlation with arterial $\mathrm{pH}$ and $\mathrm{pO}_{2}$. J Clin Endocrinol Metab 44 (1979) 888

Received June 30, 1986. Accepted August 10, 1986.

Dr. Robin S. Goland

Columbia University College of Physicians and Surgeons Department of Medicine

630 W. 168th Street

New York, N. Y. 10032, U. S. A. 


\section{Trace Element}

Anclytical Chemistry in Medicine and Biology Volume 4

Proceedings of the Fourth International Workshop Neuherberg, Federal Republic of Germany, April 1986

Editors P. Brätter P. S. Schramel

1987. $17 \mathrm{~cm} \times 24 \mathrm{~cm}$. XIII, 630 pages. Numerous illustrations. Cloth DM 295,-; approx. US \$155.50 ISBN 3110109050

The proceedings of the 4th Workshop deal with new developments in the trace element analysis of biological materials as well as with current problems in trace element metabolism, nutrition, diagnosis and the therapy of trace element related diseases.

Contents (Main Chapters) Models for Trace Element Metabolism - Trace Element in Nutrition - Trace Element Interactions - Trace Element Analysis of Body Fluids and Tissue Samples - Significance of Trace Elements in Medicine - List of Participants . Author Index - Subject Index.

Also available

Trace Element Analytical Chemistry in Medicine and Biology Volume 1: 1980. XV, 851 pages. DM 180,-; approx. US $\$ 95.00$ Volume 2: 1983. XX, 1189 pages. DM 280,-; approx. US $\$ 147.50$ Volume 3: 1984. XVI, 763 pages. DM 240,-; approx. US $\$ 126.50$

Prices are subject to change without notice

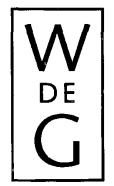

de Gruyter · Berlin · New York 